Portland State University

PDXScholar

1974

\title{
The Department of Family Services, Court of Domestic Relations, Portland, Oregon : a report of its history, function, and future
}

\author{
George Brune \\ Portland State University \\ John Hart \\ Portland State University \\ Sandra Smith \\ Portland State University
}

Follow this and additional works at: https://pdxscholar.library.pdx.edu/open_access_etds

Part of the Counseling Psychology Commons, and the Social Work Commons Let us know how access to this document benefits you.

\section{Recommended Citation}

Brune, George; Hart, John; and Smith, Sandra, "The Department of Family Services, Court of Domestic Relations, Portland, Oregon : a report of its history, function, and future" (1974). Dissertations and Theses. Paper 1750.

https://doi.org/10.15760/etd.1749

This Thesis is brought to you for free and open access. It has been accepted for inclusion in Dissertations and Theses by an authorized administrator of PDXScholar. Please contact us if we can make this document more accessible: pdxscholar@pdx.edu. 
THE DEPARTMENT OF FAMILY SERVICES, COURT OF DOMESTIC RELATIONS, PORTLAND, OREGON

A REPORT OF ITS HISTORY, FUNCTION, AND FUTURE

by

GEORGE BRUNE

JOHN HART

SANDRA SMITH

A report submitted in partial fulfillment of the requirements for the degree of

MASTER OF

SOCIAL WORK

Portland State University

1974

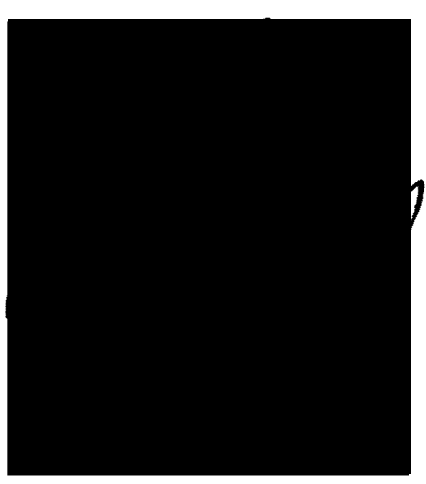


I. The Family as an Institution .......... I

II. The Agency: Maintenance of the

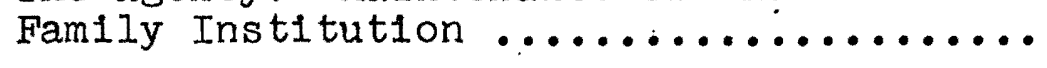

III. Divorce: Regulated Dissolution of the Family

IV. Conciliation: Strengthening and Maintaining the Family .............. 29

V. Custody: Preservation of Family Ties ... 40

VI. Visitation: Restructuring Parent-Child Relationships

VII. Allied Activities: The Agency, the Community, and the Family

VIII. Summary: Current Programs and Future Prospects

IX. Critique: Iimitations of the study ..... 


\section{INTRODUCTION}

This study was inltiated in a proposal by Mr. Donald Welch, Director of the Department of Family Services, Court of Domestic Relations, Multnomah County, Portland, Oregon .

Mr. Welch wanted to illustrate the growth and development of the agency over its ten-year history, Add1tionally; this study is a practicum project under the auspices of Portland State University School of Social. Work. Thus the study incorporates both agency and academic requirement.

The study begins with a look at the sociological foundations underlying the Department of Family Services and the social. Institutions of law and marriage and the family. In order to presert the working operation of the agency there are chapters dealing with custody and visitation and marriage and family counseling. This work is defined, and the methods involved are explained and 11lustrated. An historical overview of the agency with regard to personnel, pollcy and orientation is presented. 
CHAPTER I

\section{THE FAMILY AS AN INSTITUTION}

In order to insure an equilibrium of community Iffe and guard against the breakdown of social order, all societies provide agencies which perform regulatory and maintenance functions for the community. These regulatory and maintenance agencies are the means by which society, groups, families, and individuals are ordered and stab111zed. The Court of Domestic Relations and the Department of Famfly Services can properly be defined as belng regulatory and maintenance agencies for the institutions of marriage and the family.

Soclety is people and the basis of soclety and clvilization is people living together. As the incubator of human nature and teacher of the rules which regulate social relations, the family becomes the nucleus in the interaction of Individual and soclety. Children are born, reared, soclalized, and placed in soclety as members of families. Society guides the family in this service by providing a normative system of folkways, mores and laws, which has as one of 1 ts ends the assurances of stability in the familial institution. (4)

Social institutions are simply human endeavors to organize, maintain and fulfill basic human wants and needs. Institutions additionally operate as the systematized and regulatory forms of social adjustment. They are in essence 
the foundations of sóciety, the firmament which allows for the steady, and smooth process of community life. The term institution then "on the one side refers to certain relations between human belngs, on the other to human beings themselves united by the fulfillment of some particular function."(4) We may distinguish between analytic and concrete structures. Analytic structures never exist except in sociological theorlzing; therein, they are simply 1dealized usually single-functional structures. In the "real world" however, they are only concrete structures, which are inescapably multifunctional. The most important differentiation of roles in a basic societal structure (institution) is that involved in the corresponding core relationship. (\&)

The family then, from a soclological perspective, is a basic societal structure (institution) centered about the basic societal function of replacement. The core relationships, as mentioned above, refer to husband-wife, parent-child and sibling-sibling. A sociological definition of nuclear family, however, qualifies the requirement for one or more children. It may be argued, however, that the married couple represents the only legitimate core relationship for reproduction, that there is the potentiality for reproduction in every married couple, and It is useful for our study to include the marital relationship which is the setting for the nuclear family.(8)

"We begin with the axiom that the family is the fundamental and most important institution of society" as 
stated by Montagu. (5). The family is the social institution : which is developed around the child-mother-father-stibling relationship. It is fundamental because from it society originates and is perpetually replenished, and it is most important in that it is the principal agency for the inculcation and transmission of society's values. It is within this institution that the child first learns to be a human being, a social being, and as a result of the interaction between himself and the soclalizing condition of his particular family the foundations of his character and personality are formed. (5)

It has been the distinctive contribution of soclology to demonstrate that learning the role of others occurs through the actor's taking the role of the other, 1.e., trying to act as the other would act. One learns the behavior appiopriate to his position in a group through interaction with others who hold normative bellefs about what his role. should be and who are able to reward and punish him for correct and incorrect actions. As part of the same learning process, one acquires expectation of how others in the group will behave.

Overt role-taking is most evident and critical for children who actively and dramatically play the role of the observed parents and in this process are soclalized.

It is postulated then that the family is the basis of society, and anything that goes wrong with the family is reflected in detrimental ways in soclety. 
W1Illam Gilasser has stated, "because more families are breaking up than ever before, the family may seem more dispensable than it was in the past. The contrary is probably true."(1) Because divorce is common, many children in our society have no intact family to help them toward a successful role. These children, with less family involvement, often have a difficult task gaining a successful identity. Many fall, and hostile about their fallure, place a heavy burden on society.(1) This heavy burden is reflected In our society's rate of extreme social disorganization. "The United States has. the highest divorce and separation rates in the Western world; it has the highest alcoholic rate, the highest violent crime rate, the highest juvenile delinquency rate, the second highest homiclde rate, and the fifth highest suicide rate."(5)

Broken homes have often been accused of contributing to this social disorganization. Our society is reasonably well aware of the causes of these conditions, but does virtually nothing by way of prevention, and it is equally delinquent, with respect to therapy. (5) The abovementioned social disorganization would evidence a need for preventive and therapeutic intervention.

Since human beings are the parties to marital relationships, there is the possibility of mistakes and dissatisfaction in the choice of mates, or situations arising which make forced relationship individually or socially intolerable or undesirable. Hence, among most people there 
is divorce, that is, the standard and socially acceptable grounds for dissolution, and means of satisfying any other consequences of separation. (3) Cultural Anthropologist Ashley Montagu states: "Many marriages are a mistake -- the kind of mistake which the proper future education may reduce to the vanishing point. But while such mistakes continue to be made it is a good thing that they can be corrected by divorice. Often the realily first evidence of good sense in a marriage is the decision to divorce."(5)

It. is in dealing with divorce and the contingencies of dissolution that the institutions of family and law overlap and there necessitates a form of regulation known as social legislation. For the purposes of their own survival the responsibility for the well-being of their newborn members is assumed by the society and concern is directed toward establishing and maintaining a stable family system whatever its form.

Custom and law seek to regulate the relationship among family members by defining the rights and duties of each personal role within the family and by facilitating the Interaction between family and community. Soclety protects its interest in a functioning family by attempting control of patterns of interaction between husband and wife, parent and child and brother and sister.

Freud and later social scientists have pointed to the importance of childhood and parent-child relationships in the formation of personality patterns. It has long been 
known that family relationships, while not the sole cause, play a critical role in the causation of jưvenile delinquency. In 1934 the white House Conference Report indicated that one-half to two-thirds of all homes where delinquency was present were broken by the absence of one or both parents as a result of death, separation, desertion or divorce. The report also stressed the importance of tensions and conflicts In the family as factors in delinquency, pointing out that a psychologically broken home is just as serious a drawback to. adequate development of the child's personality as a legally broken one. The important role of the family and its members in providing this stable platform for child development is dealt with by society. Folkways and mores urge and the law orders that at least during the early period of the child's Iife, parents shall perform certain duties as a result of their responsibility to the child and, ultimately, to society.

Social Science researchers and legislators operate in an area in which their accomplishments are continually superseded by the movement of a non-static society. Legislative trends and accomplishments are always in the process of obsolescence as contemporary problems evolve.

Hogan and Ianni feel that the three contemporary issues of family legislation are: (1) the advisability of uniform laws of marriage and the family, (2) the right of the State to act in the interests of dependent members of the famlly, and (3) legal realization of the need for a soctal 
sclence approach to the problem of family unity. (4)

It has" been said that "divorce never broke up a single marriage." For the mast part it is true. Divorce readjusts status, provides legal recognition to a pre-existIng state of affalrs, ends, qualifies and creates rights and obligations, moral and legal, but it is not the enemy of the marriage, the enemies are those factors which operating within the association between men and women, first weaker and then break it.(6)

. In conclusion it would seem evident that divorce and separation proceedings are not just another form of litigation, but one aspect of a precious and complex social institution, the family, and that they have to be dealt with as a social and therapeutic problem of great and far reaching importance.

The following chapters will attempt to 1llustrate the historical development of the Department of Family Services and describe the technique and procedure utilized by the professional staff in dealing with the complex ramiflcaticns of the most basic of society's social institutions -- the family. 
1. Glasser, William, The Identity Society, Harper and Row, N.Y., 1972, pp. 133-158.

2. Grollman, Earl A., Explaining Divorce to Ch1ldren, Beacon Press, 1969, pp. 42-63.

3. Hertzler, Joyce, Social Institutions, McGraw-Hill Book Co., New York, 1929, pp. 34-37.

4. Hogan, John D, and Iann1, Franc1s A., Amertcan Soctal Legislation, Harper and Bros., New York, 1956, pp.143144.

5. Montagu, Ashley, The Humanization of Man, The World Publishing Co., Cleveland, 1962, pp. 145-181.

6. Mortlock, B1ll, The Insilde of Divorce, Constable and Co. Ltd., London, 1972, pp. 3-16 and pp. 177-202.

7. Relnstaln, Max, Marriage, Stability, Divorce and the Law, UnIver'sty of ChIcago Press, Chicago, 1972, pp. 261-277.

8. Winch, Robert F., The Modern Family; Holt, Rinehart and Winston, Inc., New York, 1964, pp. 3-33. 
THE AGENCY: MAINTENANCE OF THE FAMILY INSTITUTION The development of the Department of Family Services in the Court of Domestic Relations is a reflection of the changing thinking regarding the treatment of domestic problems. The interest in family services follows the development of the juvenile court system in the United States. The first officlal juvenile court in the United States was instituted in Chicago, Illinols on July 1, 1899. Denver, Colorado was the next city in which a juvenile court was created. The court was the result of the efforts of a great ploneer in the juvenile court movement, Judge Benfamin Lindsey, first in Denver, later of Los Angeles.(1) Judge Paul W. Alexander of the Domestic Relations and Juvenile Court of Toledo, Ohio, was another person who occupled a key position in the development of the concept of the Juvenile Court and the Family Court.

Experience revealed the need of a court where the family in all its aspects could be handled, for otherwise the legal problems arising from the effort to deal adequately with a bad family situation had to be scattered among several courts. Thus came the court of domestic relations which is now often known as the family court. These courts when they first appeared were restricted to a narrower program, having in charge enforcement of family desertion and non-support legislation. 
The Cincinnati Court of Domestic Relations was perrhaps the first to express fully the new attitude "toward. the fam1ly symbolized by the juvenile court.(2) In 1913, it took over the administration of the laws which had led to the establishment of the earlier types of courts of domestic relations, and also the function of the juvenile court and Jurisdiction over divorce, and establishment of patemity. This court under the inspiration of. Judge Charles Hoffman, had great influence over the thinking and practice of social workers upon whom so largely falls the decision, in dealing with family crists. Soclal workers were early employees of the domestic relations court system and have continued to dominate in the field.

The idea of establishing special courts with comprehensive jurisdiction in all matters of family and child welfare requiring judicial disposition has been advanced for several years by leaders in the flelds of law and soctal work, but it has been translated into practice only in a few places. It recelved impetus through the National Conference on Family Iife held in Washington, D.C. in May 1948. Even when divorce cases are heard by courts of general jurisdiction as is the present mie, the need for social investigation, especially where children are involved, has been recognized by a number of judges in several states sitting in divorce cases. In Michigan, for example, it is the statutory duty of the circuit judge of the county to recommend for appointment by the governor a "Friend of the 
Court" whose duty it is to investigate and make recommendatlons in motions in divorce, separate maintenänce and annuiment cases.

Although Oregon had juvenile court legislation early in the Twentieth Century, it was rather late in the development of domestic relations courts. Until recent years much of the domestic relations and juvenile court matters were adjudicated by county judges whose qualiflcations did not even require a law degree. Multnomah County was the first county in Oregon to place domestic relations and juvenile court cases under the circult court and to provide a circuit court juage who would handle these cases exclusively. In Multromah County, the Court of Domestic Relations has two main functions; juvenile court proceedings and jurisdiction over divorce, annulments and adoptions.

The development of the Multnomah County Department of Family Services has been an evolutionary one and can be traced almost entirely through the influence of the judges of the Court of Domestic Relations for Multnomah County and the directors of the department. Hertzler points out the fact that the history of a social agency can be garnered through the efforts of certain individuals and observes that "certain individuals have dominated institutions by force of personality of by a special acquisition of social power."(3)

When one generally thinks of the Court of Domestic Relations in Multnomah County historically the name of Judge Donald $\mathrm{E}$. Long soon comes to the fore. Judge Long served as 
the sole Judge of the Court of Domestic Relations from 1937 to 1951. During Worid War II Judge Long took his commisston In the United States Army, serving in the European Theater. In his absence; his judicial duties were assumed by several of the circuit court judges sitting on the trial bench. Judge. Iong returned from the war to find that juvenile delinquency had increased several fold in the Portland area due to the rapid growth in population and the breakdown of. family stmucture. Judge Long set out in earnest to develop programs to aid young people. He was a leader in the fight for the rights of children and was instmmental in providing facilities other than the county jall for detaining fuveniles and instituted a program whereby children taken into custody by the police were granted a preliminary hearing before a fudge within twenty-four hours wherever possible. Judge Long went on to distinguish himself nationally as a juvenile court judge and was the prime mover in the development of the juventie court and home located at 1401 N. E. 68th. In tribute to Juage Long thls facility has been dedicated as the Donald E. Long Home.

Judge Long also had a keen interest in his role as a divorce court judge. He felt strongly that the adversary process of the court room was a necessary legal procedure but that this method involving examination and cross-examination of witnesses was not always the productive and effective means to employ in assessing the abilities of the individual parents as proper custodians of children. The court room 
drama 1tself was often overwhelming to some individuals and as a result the litigants could present themselves as less effective persons than they would have under less stressful circumstances. (1)

Relying on his experience with social workers as juventle court counselors, Judge Long decided to employ a social worker to conduct a social evaluation of the two parents and to file a written report with the court setting forth the findings of the social worker and recommendation to the court as to the best custody plan for the minor children of the parties involved in the divorce action. Inftially these cases would be assigned on the basis that the parties wanted such a study. Judge Long's plans were temporarily thwarted by the fact that his domestic relations budget had no provision for a social worker. As he did have monies to hire a staff to operate the courtroom he hired the first social worker as a court balliff. Winfered Hutchins was the first social worker hired in this capacity. The social worker functioned Independent of the juvenile court.

In 1951 Judge Long was Jolned on the bench by Judge Virgil H. Langtry. Judge Long and Judge Langtry each employed a social worker to assist him on an individual basis. Ruby Page Euwer served Judge Long while Elaine O'Brien jolned Judge Langtry's staff. During this period the social workers became known as family consultants to the court and their cases were generally selected for them by the judges, usually based on the complexity of the case. The reports were 
extensive and lengthy, often containing as many as fifteen to twenty pages. Due to the amount of time involved in each Individual case the consultant's caseload was necessarliy small in number.

The family consultants came under the direction and budget of the juvenile court. In practice, however, the consultants were responsible to thein individual judge. Although . the personnel changed through the years, the number of consultants remained constant. In the early $1950^{\prime} \mathrm{s}$ Judge Carl'A. Dahl became assoclated with the Court of Domestic Relations, first, on a part-time basis and later on a full time assignment. In 1960 Judge Langtry transferred to the trial bench creating, a vacancy: Judge Jean L. Lewis was appointed to fill this position. Upon the retirement of Judge Long, Judge Jean Lewis was appointed as the presiding Judge of the Court of Domestic Relations. Judge Hawlow F., Lenon was appointed to the bench in 1961 when a new domestic relations judgeship was created by the legislature. In 1972 an additional judgeship was creatéd and Judge Mercedes Delz was elected to the position. Judge Dahl retired In 1973 and was succeeded by Judge George Van Hoomissen. This brought the court to its present complement of four judges of the Court of Domestic Relations.

Judge Lewis' term as presiding judge has been noteworthy for the changes instituted in the agency and the growth of services to the community. The staff was increased and the agency became known as the Department of Family 
Service of the Court of Domestic Relations for Multnomah County. For the first time the agency had its own direction. Much of the increase in staff was necessitated by the passage of the authorization for the implimentation of conciliation services (court sponsored marital counseling) in the State of Oregon in 1963. Oregon conciliation legislation was slow. In coming and was based on the model of the California Conclilation court system. The formal emergence of conciliation counseling by courts had its beginning with the establishment of the conclilation concept in CaIformia, The Conclilation Court of Los Angeles County was established in 1939, but 1t was not until 1955 that the first professionally trained counselors were employed by the court. This concept grew out of the awareness that throughout history, the law has enunclated the princlple of strengthening and preserving family life. But, until the emergence of the conclilation court concept, the law had no effective action-orlented program for handling such matters. Traditionaliy, the legal and soclal aspects of family breakdown have been treated as if they were separate entities. The Los Angeles Conciliation Court has rejected the separate handling of legal and social aspects and instead takes an interdisciplinary approach to working with family breakdown. This concept has taken the combination of legal and social and has shown 1 ts effectiveness in dealing with families.

There has been an increasing breakdown of the family as traditionally concelved. Divorce has been used 
Increasingly as a solution to marital problems. With this increase has come the realization by those who are professionally involved, that the courts should be concerned with considerations in addition to the legal grounds for divorce. Child custody, division of property, support payments, and other legal considerations seldom disclose the real reasons underlying the disintegration of the family. As Hogan and Ianni state,

Extra-family interest, lack of identification
with kin, adjustment to a culture which
glorifies individualism, are only a few
elements in the modern American culture
pattern which operates to weaken marital
and family ties. Yet our society stili holds
as inviolable the principles of stablilty and
continulty in family living It is the
purpose of all matrimonial iaw to ensure this
stability and continulty and of divorce law
to allow for an orderly dissolution and re-
adjustment when the marriage has been dis-
rupted.(5)

It has become apparent that since a marriage cannot be officially terminated without recourse to a legal procedure, the judiclary is in an advantageous position to provide marital counseling services for estranged couples. Until a decade ago, few such court-connected services were actually in existence.

With this philosophy the Multnomah County Court of Domestic Relations began its program of conciliation services. In August of 1963, Fred A. Hutchinson was appointed the first director of the Department of Family Services. For a time the agency functioned under the title of Family Consultant and Conclilation Services. Mr. Hutchinson was the first MSW 
hired in the department and came to the agency with considerable experience in the field of soctal service to children and families: Judge Lewis and Mr. Hutchinson visited the Conciliation Court of Los. Angeles County for a first hand observation of a conclliation court in action. Through the efforts of Judge Lewis and Mr. Hutchinson the conclilation concept received rapid acceptance in the community. Fred Hutchinson appeared before the Family Law Section of the Oregon State Bar Association to acquaint the legal community. with the conciliation movement and gained considerable. support from that body. In fact the lawyers of Multnomah County have become one of the chief sources of referrai to the court services. (6)

Under Mr. Hu.tchinson's direction there was a change In the manner of conducting the social evaluation in custody matters. The emphasis was changed from that of an invest:gation to that of a study which resulted in a greater reliance on the counselor's intervlewing and diagno'stic skills. Less emphasis was placed on interviewing collateral references. This shift in focus implied that the counselors had achieved a level of competence which enabled them to rely on their professional skills in the psychosoclal assessment of the parenting potential of each parent.

During the directorship of Mr. Hutchinson, there was a concerted effort to encourage staff members to return to college to receive their masters degrees. This policy has continued and has afforded several members of the staff the 
opportunity and encouragement to complete their graduate training. (7)

Fred Hutchinson, in an effort to develop the agency. and expand Its influence in the area of family therapy, realIy placed no restrictions on the types of cases accepted by Family Services. H1s philosophy was that any person who came to the agency with a problem was in pain and deserving of assistance which would relieve that pain. Mr. Hutchinson's regard for the client's needs was so compelling that he of ten would go to any length to provide assistance even if it meant sidestepping or ignoring rules and regulations. In a sense this philosophy has become a part of the philosophy of the agency .

Mr. Hutchinson had a strong conviction that there should be division between conciliation services (marital therapy) and consultant services (custody evaluations). For the most part this division persisted throughout his tenure as director of the agency.

When Mr. Hutchinson resigned after six years to become the director of Albertina Kerr Homes Inc., the staff had been increased to a total of seven counselors. The director's position was taken by Richard E. Collins who had previously been employed by the department as a conciliation counselor. Prior to returning to the department Mr. Collins was director of the Metropolitan Steering Committee which administered all OEO allocations in the Portland area. The name of the agency was officially changed to the Department 
of Fam1ly Services and the title of all the professional staff was changed to Marriáge and Family Counselor. As all. staff members held the same title and were placed on the same pay scale, morale was bolstered within the staff. Mr. Collins instituted further services to the community by implementing satellite offices in several sections of the clty, bringing the services closer to the clients to be served. In the area of custody studies the main change came in the increase in the number of cases handled through the agency. The number of custody cases completed by the agency has steadily increased. The length of time required to complete a custody study was greatiy reduced as well.

R1chard Collins continued the work begun by Mr. Hutchinson. His particular bias required that he expand service to the court in the area of custody and visitation cases with perhaps less emphasis on conclliation services? As Mr. Collins possessed a wide background in community affairs he was more prone to place the agency out in the community through the implementation of satellite offices and promoted the services of the agency through radio and television appearances. During his term the conciliation referrals leveled off after a steady increase over several years while the custody referrals increased dramatically. Mr. Collins had a very broad view of soclal and legislative action in the community and possessed a remarkable faculty for viewing programs not only as they currently 
existed but also as they would play a part in the future. Because of his expertise in these areas he was often called upon to assist programs outside Family Services. He assisted many agencies in wrtting federal grants and served on committees which.were instrumental in establishing day-care centers, various law enforcement training programs, criminal justice programs, and the development of a federal grants office as part of the county government.

Mr. Collins resigned to become assoclated with the University of Oregon Medical School and director of the Special Day Care Center, a treatment facility for emotionally disturbed children. Mr. Donald $G$. Welch became the director. Mr. Welch has continued the programs instituted by prior directors and has added more staff personnel through the utilization of funds from federally sponsored grants. Mr. Welch expanded the outreach program by the establishment of an office in the Albina Multi-Service: Center and the further development of services to the Southeast area. $(8)$

Donald Welch, the current director, could be seen as a synthesis of the administrative philosophies of his predecessors, Fred Hutchinson and Richard Collins. Like Mr. Collins, he has continued to support agency visibility with the maintenance of satellite offices and the encouragement of staff involvement in community affairs. His own strong clinical interests have created an agency atmosphere conduclve to Innovative counseling and staff growth as well as a tralning ground for graduate students. Additionally, Mr. 
Welch's expertise management, budget, and administration weathered the agency through a critical period of agency accountability during the current phase of county decentralization of services.

The various procedures and specific program goals will be discussed in the subsequent chapters. In order to acquaint the reader. with the legal institution which host the Department of Family Services, we will first present an outline of the divorce process. The new term for this is dissolution. 
1. Teeters, Negley $K$. and Reinemann, John otto, The Challenge of Delinquiency, Prentice-Hall, Inc., Englewood CIIffs, N.J., 1950 .

2. Groves, Ernest R, and Hoagland, Gladys, The Contemporary American Family, J. B. Lippincott Company, Ch1eago, Philadelphia, and New York, 1947.

3. Hertzler, Joyce, Social Institutions, McGraw-Hill Book Company, New York, 1929.

4. Personal interview with Judge Donald E. Long.

5. Hogan, John D. and Iann1, A., American Social Leglislation, Harper and Bros., New York, 1956, pp. 145-181.

6. Personal interview with Mr. Fred A. Hutchinson.

7. Personal interview with Judge Jean L. Lewis.

8. Personal Interview w1th Mr. Bonald G. Welch. 


\section{DIVORCE: REGULATED DISSOLUTION OF THE FAMILY}

Throughout the history of men divorce has been a source of societal concern and legislation. In the state of Oregon divorce laws date back to the year 1862. Until 1972, marriage in Oregon was viewed as a contract and in the event that one of the parties violated the contract, the injured party had recourse before the court. The marriage contract ' could be dissolved if the injured party could show that:

1. Impotency existed at the time of the marriage and continued to the commencement of the sult.

2. Adultery was committed.

3. There was a felony conviction.

4. There was habitual drunkenness contracted since the marriage and continuing for one year prior to the commencement of the suit.

5. There was wilful desertion for the period of one year.

6. There was cruel and Inhuman treatment or personal indignities which rendered ilfe burdensome.

7. There was proof of mental 1llness where the defendent had been adjudged mentaliy 111 by a court of competent jurisdiction.

The important issue here was to show that the contract had been broken by one of the parties and that the complaint was heard in a court of law. To prove their case the plaintiffs were forced to depict the defendant in as bad a light as possible. The adversary rules were applied. The defendant was served with papers charging him with at least 
one of the seven violations cited above. The wording alone was often devastating to the defendant emotionally and once the divorce process sitarted it mitigated against hopes for a reconciliation.

Once the case reached the court, the judge had the power to decide if the plaintiff had proved his case sufficlently to satisfy the law. If not, the judge could dismiss the case. In other instances the judge could rule that both: parties were equaliy guilty of breaking the contract and dismiss the case on grounds of pari del1cto. (equal guilt) In both cases the parties were locked into the marriage until they could find other grounds or could go before another judge.

The concept of divorce had as its uItimate purpose the freeing of the parties to form a new contract but they must first prove that the original contract had been broken. In 1972, Oregon adopted the so-called "no fault" divorce law. In which couples are allowed to end their marriages without blame to elther party and without iong periods of separation. A judge can grant a decree of dissolution if one of the parties can show that there are "irreconcilable differences" which have led to an "Irremediable breakdown of the marriage." In other words, 1t is no longer necessary for the breakup to be placed on the "guilty party" while the other party was alleged to be found with "clean hands." Fourteen states now have no-fault provisions in their divorce laws and several other states have liberalized their divorce 
laws.

The divorce rate continues to climb with an increase of 103\% during the years 1962-1972. There were 413,000 divorces and annulments in the United States during 1962 as compared to a total of 839,000 in 1972.

Divorce or dissolution of the marriage continues to be a legal procedure. (Hereafter the term dissolution will be used in place of divorce in conformity with the law.) If one party is dissatisfied with the marital relationship that party in order to terminate the relationship must seek out an attorney who w11I file the necessary papers with the county clerk. There is a fee for the filing which is collected by the court clerk. In Multnomah County this authority falls under the Jurisdiction of the Department of Judiclal Administration.

Once the petition for dissolution is filed with the clerk the papers are then served on the other party. The person who files the petition is then known as the Petitioner while the other party becomes the Respondent. After service of the petition the Respondent has ten days to answer the petition. The petition in addition to alleging that there are irreconcilable differences between the parties sets down the Petitioner's desires in reference to the division of the property and custody of the children. If the Respondent objects to the conditions of the petition he must seek out an attorney who w1ll assist him in filing an answer to the complaint. 
After service of the petition the court requires a waiting period of 90 days prior to granting a decree of dissolution. However, during this waiting period a pendente I1te hearing may be held to determine temporary child support and temporary child custody. In some instances the judge will issue a restraining order against one or both of the parties prohibiting them from harassment of the other party.

In the event that the parties are in agreement in regard to child custody, the case can be heard on the defauit. docket. This means that a minimum of court time is used to present the case so that the judge can establish the facts and issue a decree of dissolution. Very often the respondent does not appear in the courtroom during the proceedings.

A typical situation finds a couple experiencing marital conflict, a breakdown of communication, sexual dysfunction, and feelings of alienation and rejection. Byproducts of the marital dysfunction include financial problems, a breakdown in parent-child relationships, and employment instability.

Generally one spouse experiences dissatisfaction with the marriage and makes a pronouncement of this dissatisfaction to the other partner. There is verbalization that there is a problem in the relationship. If the other spouse also recognized that they have a problem frequently the couple can resolve the difficulty either by themselves or by receiving counseling. If the spouse dentes that a problem exists the problem will increase in dimension. 
If the complaining spouse does not recelve satisfaction from the spouse, he or she will turn to others for support. Those most frequently called upon are friends, relatives, and professionals such as physicians and ministers. At this point a separation may occur on an informal. basis without legal sanction. If the dissatisfaction persists the complaining spouse will consult an attorney to determine their legal rights. In about $90 \%$ of all divorce cases it is the wife who first contacts an attorney. Quite often the reason for consulting the attorney is to force the other partner to realize the seriousness of the problem and to force the issue to a head.

The attomey's canon requires that he explore the possibility of saving the marriage. Frequentiy on the first visit to an attomey there is no filing of a complaint. The attorney may recommend counseling.

If there is no resolution the complaining spouse will return to the attorney and request that legal action be taken to dissolve the marriage. At this point legal papers will be served on the other spouse with or without prior notification. The legal papers may include an order signed by a judge directing the person to remove himself from the home. If there has been physical conflict or if the complaining spouse can convince the attorney of the imminency of danger the court will restrain the spouse from contracting or harassing the complaintant in any manner.

If the respondent is not in agreement with the 
terms of the petition for dissolution he or she will also contact an attorney to determine their rights in the case. In the event that the parties can reach agreement the decree of dissolution may be entered by the court any time after a specifled period (90 days in Oregon) has elapsed following the service of the complaint. If there is a contest over the custody of the children or a dispute surrounding the property settlement the case may drag on for months and even years. If the parties cannot agree on the issues of child custody and property distribution, the matter must be set down on the contest docket. Evidence is introduced and witnesses are examined. After all of the case is presented the judge must make his decision.

Iater chapters w11l deal with the role of Fam1ly Services in dealing with some of the problems which are assoclated with the divorce process. 
CONCILIATION: STRENGTHENING AND MAINTAINING THE FAMILY As stated in the first chapter, all societies provide agencies which perform regulatory and maintenance functions for the community in order to insure an equilibrium within the society. A state of disequilibrium within the marriage or family is regulated by the court.

Since a marriage cannot be officially terminated without recourse to a legal procedure, the judiciary is in an advantageous position to provide marital counseling services. for estranged couples. Elkin states, "a conciliation court is more than a reconciliation court. "(1) The goal is not to. save all marriages but avold the unnecessary divorce. In the event that termination of the marriage is unavoidable or the appropriate alternative, the conciliation counselor faclitates the "uncoupling" as gently, sensitively and with as much dignity for all the family as possible.

Counseling activities can be carried on in the usually perfunctory way of attempts to reconcile marriage partners already engaged in, or ready to start proceedings for divorce; or they may attempt to help clients find a reasonable way to deal with marital difficulties irrespective of whether or not dissolution of the marriage or separation is imminent. Marital counseling can also deal with family life education, sexual dysfunction, mental or physical 11lness on a long term or short term treatment basis. 
As stated by Max Rheinstein "marriage counseling. may be limited to problems strictiy marital or it may form. part of a comprehensive scheme of family service."(2)

The complexity of marital disorganization is enormaus. Emotional conflict between married partners impacts throughout the entire extended family system and in particular impacts upon the children of conflicting parents. The adversary procedure of divorce courts frequentIy compounds the problem. J. L. Despert in Children of Divorce stated "men and women must, of course, go to the law for their decree of divorce. But when settlements involving children are concerned, when custody and visitation, maintenance and division of parental authority are to be decided, let them not bring these questions unresolved to the court." (3) The personnel of the courts do not have the time or the training to deal effectively with the emotional problems of parents and children. Family Services personnel, however, have the training and experience to anticipate the long range impact of marital conflict. It has been recognized that divorced persons benefit markedly from marriage counsel1ng. When divorce is inevitable, why not make it a learning experience? In this way, conciliation services provide preventive measures against future dysfunction and disequi11brium.

The conciliation counselor can help divorcing parents in understanding the ongoing consequences of the divorce action and in realizing that a basic of every child 
is to have a mother and a father who are in fundamental agreement. But if his parents cannot remain together, then at the very least the child must still be allowed to continue to believe in both. (2)

Publiclty in the media as well as professional journals have well acquainted the public with the growing statistics on family breakdown and the increasing use of divorce as a solution to marital conflict. With this increase has come the realization by those who are professionally involved, that the courts should be concerned with considerations in addition to the legal grounds for divorce. Ch1ld custody, division of property, support payments, and other legal considerations seldom disclose the real reasons underlying the disintegration of the family. It has become more apparent that since a marriage cannot be officially terminated without recourse to a legal procedure, the judiciary is in an advantageous position to provide marital counseling services for estranged couples. Until one decade ago, few such court-connected services were actually in existence.

The formal emergence of conciliation counseling by courts had its beginning with the establishment of the conciliation court concept in California. The Conciliation Court of Los Angeles County was established in 1939, but it was not unt1l 1955 that the first professionaliy trained counselors were employed by that court to do conciliation counseling. This concept grew out of the awareness that 
throughout history, the law has enunclated the principle of strengthening and preserving family life.

Attorneys for both sides were often in the position of attempting to preserve the family by helping to effect a reconclilation between their clients, while at the same time charged with the responsibility of providing legal services pending a divorce. Assuming both roles put the attorneys in the position of providing services for both the social and legal aspects of the client's problems. These two roles are often in conflict with each other. The attorneys were usualiy not in a position to provide the professional ongoing marriage counseling that is required when a couple's conflicts reach the point that divorce is viewed as the only resolution. Attorneys who attempted to reconcile parties seeking a divorce provided an informal service which was much needed by the community. But, until the emergence of the conclilation court concept, the law had no effective action-oriented program for handling such matters. The Department of Family Services for Multnomah County is a court affiliated marriage and family counseling agency which provides short-term crisis counseling for married couples. (See Appendix A for Oregon law setting into motion this service.) Any legally married Multnomah County resident may request services from the agency. It is not necessary that a divorce suit be pending. There is no charge for the service. Oregon statutes provide for a ten dollar additional fee in fling for all divorces when conciliation 
services are available. This in part finances the service. The balance of funding is provided by the county.

Referrals to the Department of Family Services come from a number of sources with the majority either coming from attorneys or from walk-ins who have heard of the service through word of mouth or have been referred by other agencies. In order to receive conciliation counseling from the agency, a married couple or the (husband or w1fe) requestIng the service must come to the agency, where they will initially see an Intake Counselor. During the work week, each Counselor has an assigned time to serve on intake. It Is the responsibility of the Intake Counselor to interview all walk-in clients. The Counselor makes an initial assesment of the marital situation and writes a summary of his observations. If the client or clients want to continue with counseling, a petition is signed by the client. Although signing a petition is not a prerequisite for receivIng service, the petition is the legal document which gives the court Jurisdiction in the case. (See Appendix B for Petition for Conciliation.) "A petition is binding in three ways: 1) Both parties are required to come for at least one Interview with the counselor, 2) the counselor cannot be subpoened as a witness in a later court hearing (conciliation interviews are confidential by law), and 3) a divorce cannot be issued for forty-five days after a petition has been filed."(5)

Following the request for counseling by a client, 
and the subsequent signing of a petition, a letter is sent to both of the parties by the agency requesting that they attend an informal, confidential conference with a counselor from Family Services. (See appointment letter in the appendix.) The letter indicates that the counselor will be impartial and that his (her) aim will be to facllitate discussion between the partners concerning their marital problems for the purpose of establishing new approaches to solving them. It is a general practice for each counselor during his intake schedule to retain those cases which he sees at intake, although there is no rule that he must do so. Therefore, a client's intake counselor is usually the counselor he will have in his later scheduled counseling sessions. Common or typical situations which might bring couples to Family Services for counseling might range from adultery to sexual problems within the marriage. The average couples seen by the agency have been married from three to seven years, and have pre-school children. Often the couples have been separated for several months. Frequently there is a reluctance by one of the partners to come in for counseling because of the nature of the problems within the marriage or because one of them has formed a new relationship outside of the marriage.

In the initial counseling session, almost without exception, the couple is seen together by the counselor. Future sessions may continue conjolntly, or be held separately. A number of factors are considered in the decision by 
the counselor to either see the couple separately or conjointly. Among the major factors are the nature of the problems presented, the desires of the couple, and the counselor's assessment of the situation and his recommendation for future sessions based on his educational background and experience. Often after the first or second interview, the couple makes a contract with the counselor in which they agree to work toward a certain goal in their relationship. The number of sessions is frequently prearranged by mutual agreement. At the end of the contract period, the goals are reassessed in terms of whether they are obtained, the conflict was lessened, or further counseling is in order. Statistically, one-third of the clients seen by. Family Services reconcile. It is also known that fifty percent of all the couples seen by the agency for conciliation have not been divorced five years after counseling. The Department of Family Services operates on a five day per week basis and is open Monday through Friday from 8:00 A.M. to 5:00 P.M. with evening and Saturday appointments by arrangement with the individual counselors.

During the course of conclitition counseling, three general types of situations are most frequently encountered. In the first, a couple is seen by a counselor and at least one and occasionally both of the parties have no interest in marital counseling. The counselor then directs the discussion toward an investigation of why they do not want counseling and what brought the martal relationship to its 
end. Both marital partners are guided at looking at (superficlally perhaps) what pieces of their individual behavior affected the relationship. The party with expectations of counseling being possible is dealt with and is assisted in accepting the inevitability of their spouse's decision to terminate the marriage.

A second general pattern seen finds both marital partners asking for counseling to preserve or build a marital relationship with varying degrees of individual interest. These couples are seen over a period of time and receive the benefit of sophisticated counseling techniques.

The third situation encountered has both marital partners interested and concerned but not desirous of remaining married to one another. Here the counselor assists the couple in identifying, understanding, hopefully accepting the issues that brought them to the decision to divorce. Efforts are made to assist them in dealing with the gullt, sense of fallure, and feelings of inadequacy that stigmatize divorced persons. Individual families also use the counselor to anticipate future problems and plan strategles to meet them. As stated earlier, the agency handles short-term crisis counseling for couples having marital difficulties. Each counselor does, however, carry a number of long term cases, either as therapy or maintenance cases: Often longer term cases are referred to a private therapist or to another agency which specializes in long term individual or family therapy. The number of interviews held with couples at 
Family Services generally does not exceed six (6) appointments.

The number of concillation cases handled by Family Services has grown significantly since the service was inaugurated. In 1964, 467 couples were seen in conciliation. By 1968 this number grew to 763 and then leveled off with a slight decline. In 1973, 605 couples entered into conciliation.

The professional staff, all Masters of Soclal Work or MSW's in training, come from various educational experience orientations. Treatment techniques vary among the professional staff according to individual training and preference.

A broad variety of counseling orientations are found within the current counseling staff of Family Services. Most of the counselors have strong psycho-analytic and egopsychology foundations. Other modalities which are used by the staff include transactional analysis, Gestalt therapy, the family therapy of Virginia Satir, and to a lesser degree behavior modification and group dynamics. However, it appears to be oriented towards conjoint therapy with an ego psychology theoretical basis. Supervision is a peer consultation style and staffing generally involves an every other week presentation by either one of the staff or a presentation by various medical-legal-social science professionals from the metropolitan area. In addition, there is a limited allocation in the budget for staff development and training 
outside the agency which allows the staff the opportunity to attend local seminars and workshops.

Most of the staff are members of the Conference of Counciliation Courts which is an international body of court sponsored marriage counselors and judges who work together in the conclliation courts. Several staff members are also active participants in Oregon Marriage Counselors Association. The Department of Family Services offers professional marriage counseling to the community. But even under the most favorable conditions, conclliation, being a social scientist approach to resolving marital conflict through skilled counseling programs, is not always successful. When marital partners separate, or divorce, and the custody of minor children becomes an unresolved issue, the courts are called upon to make a decision. Family Services Department plays an important function in these judicial decisions. The following chapter will discuss this involvement. 
1. Elkin, Meyer, "Conciliation Courts: The Reintegration of Disintegrating Families," The Family Coordinator, Vol. 22, No. 1, pp. 64.

2. Rheinste1n, Max, Marriage Stability, D1vorce, and the Law, University of Chicago Press, Chicago, 1972, pp. 436 b pp. 436 .

3. Despert, J. L., Children of Divorce, Dolphin Books, New York, 1968, pp. 190:

4. Ard, Ben. N. Jr., Marriage Counseling Quarterly, Assumptions Underlying Marriage Counseling, 1967, Vol.2, $20-24$.

5. Dudley, James, et al, Testing of a Deslgn for Client Evaluation of a Conciliation, a practium submitted to Portland State University, in partial fulfillment of the requirements for the degree of Master of Soclal Work, June, 1972, p. 3-4. 
CHAPTER V

\section{CUSTODY: PRESERVATION OF FAMILY TIES}

One of the main functions of the Department of

Family Services is concerned with custody and visitation evaluations. Historically, the determination of the custody of children by the courts has been based on the principie of promoting the child's best interests. The power to protect children and to act for their welfare was acknowledged to be part of equity Jurisdiction in England as far back as the Seventeenth Century, although the origin of the furisdiction remains in dispute:(1) The jurisdiction has been recognized from earliest times in the United States and is now covered by local statutes.

In marital litigation where children are involved the court in oregon may direct that a study be done to provide such information concerning the family as is necessary to protect the welfare of the children. The Family Services Department of the Court of Domestic Relations of Multnomah County has a duty to provide studies and evaluations concerning the custody of children and plans for visitation where the parents are involved in a divorce action. The legal authority for this provision has been revised and is outlined in ORS:107:425.(2). See Appendix C.

In the early days of the department all of the referrals for custody and visitation studies came directly from the court. As the staff increased it became possible 
for the scope of service to be enlarged. Currently all contested and visitation cases which are docketed by the Domestic Relations docket clerk for trial are referred directly to the Department of Family Services. A letter is sent out to the attorneys in the case over the name of the presiding judge of the court stating that unless the counsel has objection, the Department of Family Services will conduct a study. Rarely is there objection from attorneys in this regard. The procedure for the custody study has been outlined in a two-paged statement which is malled to all clients with their initial appointment letter. The custody statement serves to prepare the parties for the interview which is to follow. See Appendix D.

When a case is referred for a custody study, the counselor makes' an evaluation regarding the couples' real desire for a divorce, for counselors have found that many of the couples are really asking for help with their marital relationship. If there is sufficient indication that this is the case, the counselor may suggest that they file a petition for conciliation. If the petition is filed, the case is then transferred to another counselor on the staff for concillation proceedings are confidential by law and it would be unethical for the same counselor to handie both the conciliation and custody cases.

A second important issue is the ability of the parents to resolve the custody issue without a difficult and costly court battle. The initial premise is that parents are 
better able to plan for their family than is the court. In addition, the court plan is a limited one in that it cannot adjust for unforeseen changes that can occur in the needs of children over the years. Despert feels that it is not possible for custody arrangements to remain satisfactory over a long period. She states, "In recognition either of the court's inability to solve the tangled human equation, or of the unpredictability of human beings, the custody granted by the court is almost never permanent."(3)

Frequently the hurt and hostility between the parents is so severe that the issue of custody cannot be resolved without a study and report by the court counselor. About $85 \%$ of the custody cases handled by the Department of Family Services are settled without a court contest. In the event that the case is not settled, the counselor may be called to testify in court at the time of the custody hearing.

In conducting the custody evaluation, the counselor's maln function is to determine the level of parenting ability of each of the parents. Although there is no uniform method followed by the staff, the emphasis is on gaining an overview of the parent's history which provides such information as the kinds of things which have happened to him, his family of origin, the kind of relationships with others he has had, his conduct both within and outside of the family atmosphere, his attitude and feelings about himself and others, etc. It is important for the counselor to determine 
whether the issue between the parents is really custody rather than some other issue. The emotional needs of the children are obvious considerations. Where do the children identify -- where do they "fit" in the general scheme of things? What are the developmental needs of the children at this stage in their lives and who can best provide for them? The Department of Family Services views itself in only one of three distinct roles which are assumed during the divorce process - - that of advocate as taken by the counsel for each party, that of the psychosoclal evaluator taken by the trained counselor, and that of the decision maker taken by the Judge.

Although the Department of Famlly Services recelves most of its cases from the court docket there is an increasing number of referrals directly from attomeys requesting an evaluation prior to their setting the case for trial. Very often the attorney will request that a counselor evaluate a custody or visitation situation to determine whether the matter can be settled through social casework rather than through a court hearing. If the case can be resolved by the counselor, the parties are spared the expense and bulld up of hostility which is a natural consequence of court litigation. It is expected that the legal community will ask for additional service along these lines:

In summary, the custody function of the counselor In the Department of Family Services can be vlewed on three different levels. First, the counselor can be a catalyst in 
assisting the parents in arriving at their own plans for the children, which includes custody and visitation. This procedure is the most effective and successful mode of resolving custody issues and is used in cases where the parents' level of bitterness has not become extreme. Second, the counselor provides the two attorneys with the psychosocial information in a written report with a recommended program of custody and visitation. The attorneys often use this information with their clients to negotiate agreement without a formal contested court hearing. The third level of social work function in resolving parent-child issues occurs with the written report and recommendation providing information to the judge if the 1ssues require a contested hearing before the court. The counselor also may be used as an expert witness and provide additional information for the court during the formal hearing. This provides the judge with current data about the parents, their relationships to the children, and any special psycho-social needs the children may have. Experience has revealed that the more able the parents are to deal with planning, the better chance of a lasting resolution.

Once the question of legal custody is settled, either permanently or pendente lite, problems relating to the out of custody parent and his or her visitation with their minor children often arise. The Court of Domestic Relations refers these situations to Family Services for assistance. The following chapter w11l discuss this In more deta11. 
CHAPTER NOTES

1. Clark, Homer H. Jr., Law of Domestic Relations, West Publishing Co., St. Paul, Minn., 1968.

2. Oregon Revised Statutes 107:425.

3. Despert, Juliette Louise, M.C., Children of Divorce, Dolphin Books, New York, 1968, pp. 133 . 
VISITATION: RESTRU CTURING PARENT-CHIID RELATIONSHIPS Historically, In divorce proceedings, cause has had to be shown why there should be a divorce granted. Considerable trauma and suffering resulted from finding guilt and placing before the public eye the alleged marital indiscretions of spouses. Oregon, in January of 1971, passed a nofault divorce law. The law became effective october 15, 1972. The oregon no-fault law does away with the need for evidence of specific acts of faults in order to obtain a divorce. Under the no-fault doctrine, proof that the marriage corpus is no longer viable and that there has been an irremedial breakdown in the marriage, with no reasonable likelihood of a reconciliation, is all that is required for a divorce. Divorce, although it legally terminates the husband/wife relationship, never completely severs the ties of the individual. Vestiglal bonds remain between the pair, especially when the marriage produces children.(1)

Children are involved in the majority of divorces and the custody of the children is awarded in the divorce decree. While the laws are gradualiy changing to make the divorce process a less traumatic one of the parents, the Issue of visitation often continues to cause problems for the parents after the divorce.

In 90 percent of all divorce cases, women are granted custody of the children. Increasingly, however, 
courts are deciding that the father is the more fit parent and therefore granting him custody. Court battles over custody and visiting rights have become much more common, and often produce emotional problems for the parties involved; the parents and the children.

Visitation is a quasi-legal term which describes the continuing contract between the children and the noncustodial parent after the dissolution of the parent's marriage. Oregon law states when custody is awarded to one parent, it is usual, desirable, and proper to permit the other parent to have reasonable access to the child. The diyorce decree normally spells out under the term visitation the legal rights of the parent who lost custody. In the majority of cases the order for visitation has read "reasonable and seasonable visitation," which leaves the divorced parents in the position to decide what is reasonable and seasonable.

The expectation that divorced parents can work out reasonable and seasonable visitation which will satisfy both parents has proven to be unrealistic. Often either one or both ex-spouses remarry. Bohannon refers to the chaotic situation in households of remarriage, 1.e., the patterns of "divorce chains." These "chains" are pseudo-kinship groups . . formed on the basis of links between the new spouses of ex-spouses.(2) These groups are not uncommon, particularly. when chlldren are involved. Ex-spouses are linked together and are part of a kind of extended family. 
A man's present wife and his ex-wife might become friends. But on the other hand, bitterness or civility, at best may characterize the relationship. Continuing anger after the divorce is more often found among divorced women than among divorced men.(3) Since mo women than men are awarded custody of children at the time of divorce, the issue of visitation between the children and their non-custodial parent can often become a vehicle to keep the relationship between the divorced parents. alive and explosive.

The dynamics of the visitation issue are intricate and subtie. If the father, for example, remarries before the mother, or becomes delinquent in his child support payments because he is unwlling or unable to pay the support, the mother sometimes withholds visitation with the children.

The non-custodial parent who is ordered to pay child support may make unreasonable demands for visiting his child(ren) with the ldea that he should get something for the. money paid to his ex-wife for child support -- 1.e., his child's physical presence.

Both the causes of remarriage by an ex-spouse or delinquency in child support, and other problems cause problems in visitation. Many divorced couples make the children pawns in their personal wars against their exspouses. They are selfish and self-centered and are more concerned with their own rights and privileges than those of the children. These problems are heightened on visits. Because of the conflict and pressures that the 
child(ren) often sees or feels displayed between the parents, centered around visitation, they often develop problems that each of the parents blames on the other. Younger children often have nightmares, become withdrawn, act out in school, and reverl to bedwetting, which are all usually signs that the child is experiencing problems which he feels unable to cope with. Older children usually become hostile to one parent or both, develop problems in school such as acting out or excessive class cutting, or by muning, away from home. Charges and counter charges are made back and forth between the parents as to the sultablilty of the individual homes, the physical and moral danger to the children in visIting with the other parent, and the deep psychological damage purported to exist with a continuation of visitation between the one parent and the children. The children are trapped into a position of having to divide loyalties, making It difficult for them to show affection for one parent without feeling they have betrayed the other. The visitation problems often become too serious for the involved parties to solve. At this point elther the custodial parent, who feels he has legitimate reasons to deny visitation may seek the services of an attorney. Often both the ex-spouses retain attorneys.

When the problems of visitation are brought to an attorney, the problems cease to be seen as family problems. They are then placed in an adversary legal system which often increases the trauma experienced by the divorced couple and. 
and their chlidren. The attorney's obligation is to his client and only incidently may the best interest of the chlldren be served.

Attorneys may, in visitation cases, try to work out the problems informally between clients and attorneys without taking it to court. Or an attorney may seek a Show Cause hearing in the matter of visitation.

The Department of Family Services for. Multnomah County may become involved in the problems surrounding visitation through several means, but mainly: (1) an attorney may request that Family Services do a visitation study, (2) a judge may order that a study be done at the time of a show Cause hearing, particularly if delinguency in child support payments is one of the main reasons for denying visitation to a non-custodial parent.

After a request is made for a visitation study to be made by Family Services, appointment letters are sent out by. Family Services to the ex-spouse. The divorced parents (and their new mates) and the children, depending on their ages, are seen in Individual interviews by a Marriage and Family Counselor.

In the process of gathering information for a visitation study, whenever possible, the counselor attempts to ald the parents in focusing on the needs of the child and to set aside their own bitterness and hostility towards each other. Considerable time is spent in helping the parents understand their own feelings and to talk about them. The 
overall goal is to help make visitation a pleasant, meaningful experience for both the child and the visiting parent. After gathering information from all parties concerned, the counselor makes a written recommendation for visitation to the judge in the case. Coples of the letter are sent to both attorneys. At the court hearing, the recommendation of the counselor is taken into consideration by the judge in making his decision.

Depending on the alleged reasons for problems with visitation, the counselor sets up a recommended schedule for visitation. Where there is sufficient reason to believe that unsupervised or lengthy visits would not be in the best interest of the child a structured, supervised short visiting period is often the recommendation made by the counselor to the court. In the majorlty of cases, there is not a legit1mate reason for denying the non-custodial parent visitation with the children. Generally, based on their knowledge of child psychology and behavior, the counselor recommends that visitation by the non-custodial parents with younger children be scheduled for a few hours $(2-4)$ several times a month (usually once, a week). With older children visitation is usually recommended for longer perlods of time such as all day, overnight, or a weekend, but on a less frequent basis. An effort is made by the counselor to work out a visitation schedule that both parents can agree upon. This is in keeping with the Idea that as the children get older. the visitation schedule will need to become more flexible and 
that they, as opposed to the courts, are in a better position to adjust visitation to the needs of all concerned.

Visitation rights by the non-custodial parent with the child is guaranteed by the law unless the visits would not be in the best interest of the child from a physical or moral standpoint. Visitation is increasingly becoming a problem for divorced parents and their children.' The problems surrounding visitation are being increasingly brought before the courts in an attempt to work out solutions to the problems.

The number of visitation studies done by Family Services has continued to increase in numbers. In 1965, 48 visitation studies were done. In 1973, the number of visitation studies completed totaled 140.

While the primary focus of the Department of Family Services is on direct service to families and to the court, the possibilities of providing a source of advanced training for professional counselors and preliminary research into family phenomena has not been overlooked. Over the years, many "student-trainees" have recelved close supervision around services provided by the Department. Several research groups have also used material to develop written projects. These activities are discussed in the following chapter. 
CHAPTER NOTES

1. Robbins, Norman N. "There ought to be a Law! Have we Found Fault in No Fault Divorce?", The Family Coordinator, July 1973, Vol. 22, No. 3, pp. 359.

2. "Rising Problems of 'Single Parents"", U.S. News and World Report, July 16, 1973, pp. 35.

3. Bohannon, Paul (Ed.), Divorce and After, Doubleday \& Company, Inc., Garden CIty, New York, 1970, pp. 127-139. 
ALLIED ACTIVITIES: THE AGENCY, THE COMMUNITY, AND THE FAMIIY - Throughout most of 1ts history, the Department of Family Services has been actively involved in a number of community activities and has served as a training base for social science graduate students.

Academic year 1966-67 was the first year that students from Portland State University School of Social Work were involved in two-day a week "field work" at the court. The two graduate students were supervised by Mrs. Joyce Mowry. The field work experlence allows the student an onthe-job type of learning experience, enabling them to gradually assume increasing amounts of responsibility, and professional expertise under the tutelage and supervision of a professional staff member. After a period of orientation to administrative procedures the students sit in on staff members cases, are assisted with family consultant custody and visitation cases and begin some conciliation counseling usually with weekly consultation and evaluation from the supervising staff members.

The following academic year 1968-69 there were no social work graduate students assigned to the department, however, there were two undergraduate students who worked as volunteer social work aides in return for the supervision and training experience. 
social work students who were supervised by Mr. Donald Welch. Mr. Welch, who is presently the director of Family Services, continued the supenvision of graduate students until the academic year 1972-73 when Mrs. Patricia Sims was student supervisor. Mr. Welch believes that the field work arrangement between the School of Social Work and the agency has been a benefit to both parties particularly when those students assigned to the agency have had some prior human services experience and have a human behavior and psychology academic background.

The Department of Family Services has also hosted Ph. D. level. Psychology Interns. The interns have been supervised one day a week by a staff member as part of a three-month community service program sponsored by the Portland Veterans Administration Hospital and directed by Dr. Vincent Glaudin.

Another education and training program was initiated during the 1968-69 academic year by Mr. Richard Collins who was at that time director of the Department of Family Services: Mr. Collins began a lecture and discussion series for third-year medical students during their public health rotation. The focus of the series was on the psychosocial impact of divorce on young children through case discussion and observation of court proceedings. The inttial series of lectures has developed into an on-going program and at the present time medical students are at the court one afternoon each month. 
There was also an arrangement during the 1968-69 academic year between the University of Oregon Medical School, Department of Psychiatry and the Department of Family Services in which first year psychiatry residents rotated through the agency for two-month periods. The residents worked with child custody cases focusing on those cases with young chlldren. Mr. Welch was the agency supervisor for this program. The program became inactive at present but may be renegotiated in the future.

In addition to the formal internship and training activities, the Department of Family Services staff members have been involved in various community activities. Mrs. Patricia Sims has served as a special consultant on family If fe for the Portland Police Academy and the Washington State Highway Patrol.

Research is another means by which Family Services has not only met Multnomah County goals of service accountability, but also provided meaningful knowledge to the flelds of soclal science and social legislation. The agency has been a resource for graduate research studies. Over the past few years at least eight group theses have been written around material from the agency. At this writing an ongoing in-practice research program is being planned which would provide evaluative data on the effectiveness of the various services performed by the agency. Writing and publishing the subsequent data could significantly add to the literature on the theory and techniques' involved in custody, visitation, 
conciliation, premarital and post-divorce counseling. The King County, Washington, Family Court Conciliation Service RESEARCH IN PROGRESS REPORT, 1968-72 indicates that research-in-practice can develop staff capability for continuous program evaluation and that the resultant information has alded domestic court judicial programs.

Th1s chapter has attempted to provide an overview of the numerous activities with which the Department of Fam1ly Services is involved. The agency has endeavored to keep pace with new developments technicaliy and theoretically in social science and social legislation by providing a learning center for graduate students, a resource center for new research, and in planning for a research-1n-practice development. The Department of Family Services should continue 1 ts tradition as a dynamic, growing agency providing skilled and sensitive professional help to its clients, the Court of Domestic Relations, and the community at large. 
SUMMARY: CURRENT PROGRAMS AND FUTURE PROSPECTS Beginning with one special balliff charged with Investigative powers by the Circuit Court Judge, a department of elght professionally trained counselors has evolved, providing a broad range of services. This counseling staff serve as consultants to the four judges comprising the court of Domestic Relations. They further provide psycho-social written evaluations to the practicing attorneys who represent the divorcing couple. A variety of counseling and community services have been provided to nearly 2,000 familes annually. No-fault divorce has made some init1al inroads in ameliorating the hypocrisy and trauma of family litigation. Prior laws required marital partners to publicly accuse each other of major faults. Witnesses were used to support these accusations and court hearings frequently became a very painful and destructive experience. Parental plans for child custody and visitation when subjected to rule of evidence and cross-examination became distorted and untenable. The new divorce laws did not reduce this area of family conflict. Social work services used adjunctively with the court process remains the primary attempt to accommodate the psychological elements associated with family separation and the termination of personal relationships.

Divorce has been viewed as bad. In recent years this stigma has been reduced to some extent but public 
resources have been used to save marriages. Oregon's concillation law vested this task in Family Services. Currently the counseling goals for the department have expanded to include assisting couples to deal with divorce and to make plans based on a more rational emotional atmosphere. (Conciliation in one sense means to reach agreement.) Using a variety of counseling techniques, marital partners are helped to plan together their future relationship. This plan can be to remain married or to divorce. In both instances the Family Service counselor focuses the couples' attention on their specific situation and assists them in making decisions.

State law enables county governments to establish such counseling services ancillary to the divorce court. UsIng the legal authority of the court, resistive clients can be forced into counseling by use of civil subpoena. While. Family Services has this degree of control, they rarely use 1t directly but do imply its use in order to reach some marital partners. The primary goal is one of having the couple meet together in a neutral territory and with the assistance of a counselor discuss their present situation, their mutual history, and plans for the future. 'Secondary goals are directed to changing behavior and attitudes. Custody disputes involve, two ex-intimates who can no longer share the parental responsibilities of family life. The legal guidelines are broad and not much help in individual situations. Custody of a minor child; by the dictates of 
law, should be vested with that parent who can meet "the best interests of the child."(I) Case law made by Supreme court decisions does not define this further as there have been contradictory rulings over the years. Family Services, using soclal work counseling techniques, and the authority delegated by the Court, attempts to tallor a program that protects the children and reduce the conflict of a formal trial. The parents are first helped to develop and accept their own plans for custody. Failing here a formal written evaluation is prepared with a specific plan recommended. This written report is provided to the attorneys where a second level of planning can occur and a negotiated program of custody developed. The last level of resolution occurs when the social work counselor presents to the judge in a formal court hearing specific information and a recommendation as an expert witness concerning custody of minor children. With the granting of divorce and the awarding of legal custody of the children, the court is left with an Issue of the relationship between the children and the noncustodial parent. In most instances this visitation program Is left in the unspecific terms of reasonable and seasonable visitation with the minor children. Basically this allows the parents to adopt their own program and leaves most control with the custodial parent. Family services becomes. involved when parents have serious problems with such general terms; and develops a specific program of visitation. Such a program becomes a written plan which both parents are helped 
to accept and use to benefit the children. As with custody evaluations, individual families may require the additional services of attorneys and possibly a formal court hearing. In both areas of custody and visitation problems faced by divorcing families, the Department of Family Services has a goal of reducing the conflict and assisting the individuals directly involved to more objectively plan. for their future.

Counseling programs reach only those family situations that have progressed to a serious stage of conflict. In a sense these could be termed rehabilitative services. A broader approach and one that most service agencles do to a degree, is the preventive services associated with educational programs. Family Services has attempted through several allied activities to address marriage and family problems on this broader scale. Individual counselors have met with vartous public groups to discuss many facets of family life. Many different research programs have been conducted using both agency cllents and counseling staff. For several years students have recelved internship supervision from Fam1ly Services. These students have included lay persons, social workers, psychologists, and child psychiatrists.

Future prospects for Family Services will be tied. to changes in the broader soclai institutions. Family Services will continue to operate with the same basic programs now functioning. Hetero-sexual pairs continue to marry, and remarry, in larger and larger numbers. These 
intimate relationships will continue to develop problems and such problems lead people to seek solutions. The court structure dealing with family problems is well entrenched and has the support, in varying degrees, of soclety. These two forces meet in the court-connected programs of Family Services.

The first change that seems likely to effect programs within Family Service is the new County reorganization of departments. In the past the counseling programs were extensively related to the Domestic Relations Court and for the most part were physically housed near the Court rooms. County plans call for a much broader geographic spread to service dellvery and much of Family Services counseling efforts will occur away from the Courthouse.

A second area of new policy for County government Involves greater use of multi-discipline teams to provide a broad varlety of services to residents of the county. In all I1kelihood, Family Services counselors will be responsible to some degree in working on teams with other professionals represented. Current thinking has teams with Community Health Nurses, Mental Health Counselors, Juvenile Court Counselors and Adult Parole and Probation Offlcers. These teams will certainly open a new area of counseling or consultation service for the Family Services professional.

In the past the staff have occasionalily offered short-term counseling using a group modality. Several current staff members have discussed the need for such a service 
as part of the on-going program for Family Services. This interest, coupled with the potential of increased referrals from multi-discipline teams, will certainly result in much greater use of group counseling.

The first groups formed may be composed of individuals experiencing considerable difficulty in adjusting to the loss of their marital partner as a result of divorce. Family Services has identified sizeable numbers of such clients and on a time-available criteria have provided limited counseling assistance. Preliminary plans already call for the identification of such persons and two counselors may pool their current divorced clients into such a group.

Fees for service have been a much discussed theme within County government. For several years the Mental Health Clinic has used a sliding fee scale with its clientele. Family Services staff have discussed such a theme but have not made efforts to implement such a change. Wlth tax monies becoming even more scarce, it seems Inevitable that fees will become part of the practice for Family Services. Some families have need of and request appointment times outside of the 9:00 - 5:00 workday. Without formalizIng a program individual counselors have sporadically provided Ilmited evening and Saturday appointment times to meet this need. There are now more counselors available and some Indications from administrative staff with the county to formalize evening and weekend appointment times. One person has also suggested a 24-hour service for severe domestic 
crises. Currently these family problems are left to the law enforcement agencies or hospitals. Considering the acuteness of many such family outbursts, that is a high likelihood of violence even to the point of homicide, services patterned after Sulcide Prevention would seem productive. Domestic crises services would also create a closer working relationship between Family Services and the two local police departments. Intervention into family conflict at this early point could be considered preventive services, if the counseling efforts are successful in reversing the spiral of family breakdown.

Earlier intervention of counseling services could also come about from two other contemporary developments. First, the Circuit Court legal files are current non-computerized. All legal suits are assigned numbers in numerical order regardless of the type of action. With computerization the ability to identify divorce filings and extract mailing addresses for the spouses can be easily accomplished. In the past, plans to mail information relating to the availability of counseling to divorcing families has been thwarted by the problems of Identifying the couples. Farly intervention could be particularly helpful.

Second, early intervention using a broader educational program seems quite possible with the development of cable televiston. Increased accessibility to television without cost would allow for Family Services to develop a program aimed at encouraging families with problems to seek 
outside assistance. The program could also deal with the problems experienced after divorce when children are faced with developing ways of living with two families. With even greater numbers of children experiencing divorce, services in this area need greater development. Family Services and its ties to the Domestic Relations Court are located at a key point for developing new programs. Such new services are likely to involve greater follow-through with serious problems between children and their custodial parent. Current practice is to end service (a few exceptions occur) when the divorce decree is finalized by the court. Many parents have Iimited capacity to care for their minor children and yet are sufficiently provided with other resources as to not qualify for on-going services by the Juvenile Court, State Children's Services, or Public Welfare. Future developments could find counselors from Family Services providing services to such families after their divorce.

Changing sex gendered roles, values and attitudes have resulted in fathers playing a much greater part in the care of infants and young children. Divorce finds these fathers seeking custody of young children: Family Services currently responds to custody issues only where both parents seek legal custody in divorce. Where only one parent asks the Court for custody, evaluative and counseling services are not offered. Twice in the last year, fathers have sought custody of infants without the child's mother contesting. 
Both situations were viewed as possibly inappropriate by the Court and referred to Family Services. It appears likely this will lead to a program requiring, in some form, that Family Services review non-contested custody programs for young children.

In the past most divorces found at least one attor ney involved with preparing the legal forms necessary to effect the court action. Attorneys are officers of the court and professionals with an established code of ethics. The Domestic Relations Court judges have assumed the attorney would not be party to a grossly inappropriate custodial proin. . . 1. gram for children. Recent sentiment against the fees charged by attorneys have resulted in many childless couples to filing their own divorce forms. These non-attorney involvements may in the future extend to couples with children. If these occur, it is highly likely Family Services will again be asked by the courts to review and comment on the appropriateness of such non-contested situations.

Recent legislation(2) now allows for the judge to appoint an attorney to represent the children during their parents' divorce. With this third attorney in the advocary process, the role of Family Services during the formal trial may be greatly increased. Historically, the counselor has been used as a witness for the petitioner or the respondent. Where the children have legal representation the counselor could be called as a witness for the children. Too, the children's attorney might be freer to call other witnesses 
for the children. The Family Services counselor could suggest important persons to the individual situation as well as assist the children's attorney to develop lines of questionIng to bring before the judge broader information.

Visitation between children and their non-custodial parent have received some attention by Family Services. This is an area with great possibilities for service in the future. Most divorced families are left to their own devices to adjust visitation to meet the changing needs of children. The counseling staff of Family Services have developed considerable knowledge related to this area and could provide an educational-styled program to share this information with divorced families.

Closely related to issue of conflict around visitation is the payment of child support. Currently Family Services are not involved in problems of child support. Each County has responsibility for providing legal assistance to children (usually through the parent with legal custody) around the securing of financial support from their parents. This responsibility is exercised through the District Attorney's office and tends to be focused on contempt of court procedures. If a parent is found in contempt of a court order, they can and sometimes are sentenced to a short period of jail. Future developments could find Family Services working with both the District Attomey and the Parole and Probation officer to develop alternatives to this process. 
The District Attorney is also charged with legal responsibility in matters of establishing paternity. Several broad social forces such as increased numbers of non-legal marriages and legal rights of unmarried fathers may offer opportunities for Family Services to provide social services adjuncture to the legal process.

New forms of family groups are also being experimented with by sub-groups with the larger society. Children born into these groups may require new approaches if the experiment breaks down and individual members seek to change their styles. The services of Family Services appear more responsive to change than the more authoritarian model of the legal institutions and may respond with new services to such breakdowns.

Remarriages of parents result in large numbers of familles having step-relationships. These blended family systems face unusual adult-child problems. Even today Family Services becomes a service to a few such situations as they return to Court for modification of divorce decrees. Future programs aimed directly at this population group seems a natural outgrowth of current trends.

Marital partners experiencing problems and divorced adults with unsolved conflicts are requesting counseling services in the broader community. These results are providing a market for private practicing counselors and these counselors are beginning to develop a formal organization. The Oregon Association of Marriage and Family Counselors is a 
growing body, with interest in licensing and regulating through legislation. Such changes could have far reaching effects on Family Services. As a beginning the avallability of competent counselors will lead to greater referral by Family Services. Later developments will hopefully ald in keeping a high standard of service for Family Services even in the fact of restricted governmental spending. Other changes of State laws could have direct effects on the function of Family Services. Current laws dealing with both Conciliation Services and Custody Evaluations are enabling in nature. That is, County government may provide such adjuncture services to the courts sitting in their county. Should these laws become mandatory as suggested by a few judges, all County governments within Oregon would establish agencies similar to Family Services. Formal exchanges, training of staff, and broader organization programs would no doubt result for Multnomah County Family Services.

Other changes of law, espectally the adoption of a Uniform Divorce Law for all. 50 states could lead to more national organizational efforts, closely akin to that discussed for Oregon.

To this point we have discussed continued humanistic changes as they would affect Family Services' future development. With some reversais of this mood on several fronts, such as New York's laws related to dmigs, California's approach to Public Welfare, and citizens reaction 
throughout the United States towards the death penalty for capital crimes, divorce and social services for these situations could easily be made very restrictive. A quick swing of history's pendulum and twenty years of development such as discussed in this project could be brought to a close. In closing the discussion of future prospects, recent policy changes by the Board of County Commissioners has resulted in the development of a county-wide program aimed at measurement and formal evaluation. An office of Planning and Evaluation is now in existence. This staff reports directly to the Board and have been charged with developing a system of measuring productivity. Sophisticated evaluations are creating needs for individual program managers to reorganize elements of their service delivery and to develop instruments to measure output other than in terms of caseloads. Famlly Services is currently discussing methods of measuring outcomes of counseling. As a system becomes operational this may result in changes within their program.

Regardless of the future prospects for Family Services, they w1ll measure thelr developments and a computer will analyze, store and spew forth its print-outs. We feel the basic programs now operating are essential for saciety and that they provide support for family development. Hopefully the future w1ll support rather than limit such services to c1tizens. 
CHAPTER NOTES

1. Oregon Revised Statutes, 107.105.

2. Oregon Revised Statutes, 107.425. 


\section{CRITIQUE: LIMITATION OF THE STUDY}

Reviewing this study identifies several areas where additional efforts were needed as well as problems encountered that limit the quality of the completed project. These IImitations will be briefly outlined to hopefully assist future researchers in their study of dynamic systems. The broad design followed in collecting the material for the study falled to include a plan for obtaining and presenting a sense of historlcal perspective around the points of change with Family Services. Since this agency is a small system linked to the court and community the changes in program could have been better understood if the study had included information relating to at least these two dynamic forces.

A second oversight in design occurred in collecting information from personal interviews with the circuit court Judges and the former directors. These interviews were completely unstructured and without a speciflc focus. Each was recorded using a portable tape recorder but due to their length not transcribed. Further researchers are cautioned in this area and urged to develop a stmuctured interview with easy transcribing potential. If possible, this data collection design should also build in the possibility for at least one follow-up interview. The last design problem occurred around the development of a time table for the study. The 
study group falled to set up a clear beginning and ending date so were caught up with studying a system in motion. During the sixteen months the study was in progress, Family Services continued to function as an open system. As such, subtle changes were occurring which caused the study to never have a completed qual1ty. Although an ending date appears artificlal, we belleve it would have been of assistance had it been established before the study began.

The agency itself presented limitations for such a historical review. The most serious limit was the absence of recorded material. The agency maintains almost no correspondence files and only minimal material on formal judicial policy statements. Generally agency documents are oriented towards individual client services rather than broader program goals or formal policy. Even the data collection systems for case reporting are limited and deals primarily with numbers served rather than results.

There were no annual reports, minutes of meetings, or year by year written budget proposals. These IImitations place great stress on describing the agency and requires almost exclusive use of members of the staff and their memory of what happened historically.

The final limitation is not easy to discuss as it involves the three authors of the study. All three have been or are employed by the agency studied. Being on the staff of Family Services had to create subtle biases in studying "our agency." It also had to influence the material provided us 
by the staff, former directors, and the judges. We anticipated this problem from the beginning and attempted to remain objective throughout. We feel we were successful for the most part but would recommend that future researchers not attempt to study systems in which they are an integral part unless they are willing to live with such limits.

In closing this study we would address the positive points of our efforts. We have pulled together a ten-year history of a small public agency and provided a document for study. Since this is the first attempt Family services has made to look at its development in a systematic manner, this study could be considered the beginning of a new awareness. Hopefully Family Services will continue to record its development. It is a worthy project. 


\section{APPENDIX A \\ OREGON CONCILIATION LAW}

CONCILIATION SERVICES

107.510 Definitions. As used in ORS 21.112 and 107.510 to 107.610:

(1) "Conciliation jurisdiction" means domestic relations conciliation jurisdiction and authority referred to under ORS 21.112 and exercised under 107.510 to 107.610 by a circult court in any controversy existing between spouses which may, unless a reconciliation or a settlement of the controversy is effected, result in the dissolution or annulment of the marriage or in disruption of the household.

(2) "Conciliation services" means domestic relations counseling and related services obtained by a circuit court exercising conciliation jurisdiction and used by the court in exercising that jurisdiction.

(3) "Domestic relations sult" means suit for dissolution of the marriage contract, annulment of the marriage or separation from bed and board. (1963 c. 434 1: 1971 c $280 \cdot 24)$

107.520 Establishment of conciliation jurisdiction. The circuit court for any county or the circuit courts of mote than one county comprising a judicial district after making a determination that the social conditions of the county or district make it desirable to establish conciliation services for the full and proper consideration of domest1c relations sults filed in such county or district may exercise conciliation jurisdiction and obtain, use and provide conciliation services referred to in ORS 21.112 and exercised under ORS 107.510 to 107.610. After conciliation jurisdiction has been established the circult court or courts of such county or district may at any time determine that the need for such service does not warrant its continuance and terminate the same.

(1963 < 4342 ; 1965 c 6251 ; 1971 c 280 25)

107.530 Source of conciliation services; county to pay expenses. (1) A circuit court or the circuit courts of a judiclal district exercising conciliation jurisdiction may obtain conciliation services by:

(a) Employing or contracting for counselors and other personnel; or

(b) Contracting or entering into agreements with public 
or private agencies to provide conclilation services to the court or courts.

(2) Subject to the provisions of the Local Budget Law, the compensations and expenses of personnel performing conclilation services for the circult court or courts and other expenses of providing conciliation services may be paid by the county or as may be agreed upon between the counties involved.
$(1963$
c 434
3; 1965 с 625
2)

107.540 Conciliation jurisdiction by court; effect. Whenever any domestic relations suit is commenced in a circult court exercising conciliation Jurisdiction and providing conciliation:services, the court may, in its discretion, exercise conciliation jurisdiction over the controversy and over the parties thereto and all persons having any relation to the controversy. If, within 45 days after the court commences to exercise conciliation jurisdiction, a reconciliation or a settlement of the controversy has not been effected, the domestic relations suit shall proceed as if the court had not exercised conciliation jurisdiction. $(1963$ c 434 4; 1971 c 280 26)

107.550 Petition for conciliation jurisdiction; contents. (I) Whenever either spouse or both spouses file In a circuit court exercising conciliation jurisdiction and providing conciliation services a petition requesting the court to exercise conciliation jurisdiction with respect to a.controversy existing between the spouses, the court shall exercise conciliation jurisdiction over the controversy and over the parties thereto and all persons having ariy relation to. the controversy.

(2) The petition shall:

(a) Allege that a controversy exists between the spouses and request the aid of the court to effect a reconciliation or a settlement on the controversy:

(b) State the name, address and age of each spouse and the date and place of marriage;

(c). State the name, address and age of each minor child of the spouses or either spouse;

(d) State, if known, whether a domestic relations suit involving the same marriage is pending in any other court in this or any other state, and

(e) State such other information as the court, by 
mule, may require.

(3) No fee shall be charged for filing the petition.
$(1963$ c 4345 ; 1965 c 6253$)$

107.560 Effect of petition. A petition may be filed under ORS 107.550 whether or not a domestic relations suit in which the spouses are parties has been commenced. When a petition for conciliation jurisdiction is flled no trial or hearing on the merits of a domestic relations sult between the parties shall be had until after the expiration of 45 days from the filing of the petition; provided, however, that during this period the court may use its full equity powers to protect and preserve the rights of the spouses. $(1963$ c $4346 ; 1965$; 625 4)

107-570 Notice; attendance at hearings. When a circuit court undertakes to exercise conciliation jurisdiction pursuant to ORS 107.540 or 107.550 , it shall refer the matter to the conciliation services provided by the court. The court shall cause notice to be given to the spouses of the undertaking to exercise conciliation jurisdiction and the authority therefor, whether under ORS 107.540 or 107.550 , and of the time and place of any hearing, conference or other proceeding scheduled pursuant to the exercise of conclilation jurisdiction. The court may require the attendance of the spouses and of witnesses as. In other civil cases. $(1963$ c 4347 )

107.580 Restriction of services; priority where children involved. Whenever a circuit court determines that the conclilation services provided by it are not adequate for the proper disposition of all matters that may be referred to the services under ORS 107.570; the court, by rule, may restrict the services provided, but shall give priority to controversies in whioh the spouses have children under 15 years of age whose welfare is involved in the outcome of the controversy. $(1963$ c 4318$)$

107.590 Court orders; reconc1liation agreements. (1) A circuit court undertaking to exercise conclilation jurisdiction pursuant to ORS 107.540 or 107.550, with the consent of the spouses, may make orders with respect to the conduct of the spouses and with respect to the subject of the controversy as it considers necessary to preserve the marriage or to implement the reconciliation of the spouses; but an order shall not be effective for more than 60 days unless the spouses consent to a continuation of the order. 
(2) any reconciliation agreement between the spouses may be reduced to writing, and, with the consent of the spouses, the court may make an order requiring the spouses to comply fully with the agreement.

(3) The court may at any time terminate or modify any order previously made. (1963 c 434 9; 1965 c 625 5)

107.600 Privacy of hearing; confidentiality of communications; records closed. (1) All hearings, conferences and other proceedings held pursuant to circuit court exercise of conciliation jurisdiction pursuant to ORS 107.540 or 107.550 shall be held in private, and all persons other than officers of the court, conciliation services personnel, the spouses, their counsel and witnesses shall be excluded.

(2) All communications, verbal or written, between spouses and from spouses to counselors, the court, attorneys, doctors or others engaged in the conclilation: proceedings; made in conciliation conferences, hearings and other proceedIngs had pursuant to the exercise of the court's conclliation jurisdiction shall be confidential within the meaning of paragraph "(e) of subsection (I) of ORS 44.040.

(3) All records of the court with respect to exercise of conclilation jurisdiction shall be closed. However, any petition flied under ORS 107.550, any written reconciliation agreement between the spouses and any court order made in the matter may be opened to inspection by either spouse or his counsel upon written authorization by a judge of the court.

$(1963$ c 434 10; 1965 c 625 6)

107.610 Qualifications of conciliation counselors. Persons performing conciliation services referred to in ORS 27.112 and exercised under. ORS 107.510 to 107.610 shall have minimum educational and experience qualifications of a master's degree in the behavioral sciences; or a bachelor's degree and one year's graduate training, both in the behavloral sciences plus two years paid case work. or clinical experience; or a bachelor's degree in the behavioral sciences plus four years' paid case work or clinical experience. (1963 c 434 12; 1971 c 280 27) 


\title{
In the Circuit Court of the State of Oregon
}

FOR THE COUNTY OF MULTNOMAH

\author{
DEPARTMENT OF FAMILY SERVICES \\ Conciliation Services \\ Department of Domestic Relations
}

Upon the petition of

\begin{tabular}{lll}
\hline Applicant \\
and concerning \\
\hline
\end{tabular}

PETITION FOR CONCILIATION $\mathrm{CC}$

D

The applicant in the above entitled cause respectfully represents to the Judge of the above entitled Court:

A controversy exists between the above nanied husband and wite, and the aid of the Court is requested to effect a reconciliation or an amicable settlement of such controversy.

Appliçant's malling address is:

Applicant's phone number d.o.b. Age

Spousệ's mailing address

Spouse's phione number is d.o.b. Age

Date and place of marriage

Do you have minor children? No _ Yes

If so, the name and d.o.b. of each child.

Is therc a dissolution pending in this State? in any other State?

The names and addresses of other persons who have a relation to the controversy, and who are also named as respondents herein, are:

Your.applicant prays that this. Honorable Court make such orders in respect to the conduct of the husband and wife and the subject matter of the controversy as the Court dcems necessary to preserve that marriage, effect a reconciliation of the husband and wife, or an amjcable settlement of the controversies involved.

1 certify that $I$ make this petition in good faith with the hope of effecting a reconciliation with my (husband) (wife); I promise that for at least 15 days after the Court accepts jurisdiction to lend aid in reconciliation. I will not do any thing to prejudice the interest of my (husband) (wife): that I will not conceal, divert or dispose of any asset in which my (husband) (wife) has, or plans to have, an interest: that I promise to do my utmost in effecting an amicable settement of the controversies presently existing in my family.

Dated:

at . Oregon

Attorney for Applicant (if any)

Address $\frac{\text { Allorney for Spouse, (if any) }}{-}$




\section{APPENDIX C}

ORS 107.425 Investigation of parties in domestic

relations suits involving welfare of children; counsel for children; staff. (I) whenever a domestic relations suit is flled, or whenever a habeas corpus proceeding or motion to modify an existing decree in a domestic relations suit is brought before the court, the court, having jurisdiction may, in cases where there are minor children involved, cause an investigation to be made as to the character, family relations, past conduct, earning ability and financial worth of the parties to the suit for the purpose of protecting the children's future interest. The court may defer the entry of a final decree until the court is satisfied that its decree w111 properly protect the welfare of such children. The investigative findings shall be offered as and subject to ali the rules of evidence.

(2) The court, on 1ts own motion, may:

(a) Cite either party to the suit to appear and testify as a witness during the investigation; and

(b) Appoint counsel for the children. A reasonable fee for an attorney so appointed may be charged against either or both of the parties or as a cost of the proceedings.

(3) The court having jurisdiction of cases described in subsection (1) of this section may hire and affix the salaries of such professional and clerfcal personnel as are necessary to carry out the purposes of this section. The salarles of the professional and clerical assistants shall be paid in the same manner as the salaries of county officers are pald. 


\section{APPENDIX D}

\section{A CUSTODY STUDY}

A descriptive and informative statement for the client of the custody process.

We have prepared this statement for our clients and thein attorneys concerning what happens when the Court orders the Family Consultant office to conduct a custody study. An order for a custody study is agreed upon by both attorneys and the court, and after the study they receive copies of the report. The counselor or counselors who have worked with the family may be questioned about the report in court by either attorney, and the parents may be present during the questioning.

\section{PURPOSE OF CUSTODY STUDIES}

In a custody study we try to decide which parent can best provide a home that meets the children's individual needs. Important factors to consider are: the personalities of the parents and children, the quality of the relationship between them, the growing needs of each child (considering age and sex), the children's preferences when their age and maturity permit, and the practicality of each parent's custody plans.

This is obviously a complicated operation because each parent -- by human nature -- has both favorable and unfavorable qualities. Also, because a growing child's needs change during his development and the parents' situations change, it is possible that recommendations for parental custody could change in time.

Remember that a custody study does not find one parent fit and the other unfit; we find, in most cases, that both parents are able custodians.

\section{WHAT THE COURT COUNSELOR DOES}

The ordinary procedure is for the counselor to interview both parents at length. Often the children are interviewed and, when practical, the children and parents are sieen together. References interviewed are usually limited to professional persons -- teachers, school counselors, clergymen, soclal workers, doctors and psychiatrists -- who have been close to the family.

In general, we do not interview frlends and neighbors because we have found their testimony is less blased and more meaningful if given in court under legal rules. However, we may selectively interview friends or neighbors if they have 
- specific information which may clarify the case.

Occasionally one parent w1ll ask a counselor to make an unscheduled visit to the other parent's home to observe improper child care. We have no rule against such visits and do make them when they seem appropriate. On rare occasions they are helpful. But most often we have found such visits inefficient and unrevealing; therefore, we carefully consider doing this.

It is important to remember that a custody study is a social evaluation by a social worker and not by a detective. We do not get evidence by following people or by watching their homes. Under special circumstances such methods may be appropriate for proving a case in court, but these are not the methods of our profession. And, as a rule, we do not try to prove or disprove allegations because this is done more effectively in court.

We know our study is not always the only factor to be considered in a custody decision. Evidence gathered by surveillance and the testimony of witnesses not interviewed by the counselor may also be meaningfiul and may add another dimension to the case.

Our department offers various services for parents who want to understand themselves and their families better. These methods often help parents resolve their. custody differences, separate on friendly terms and remain effective parents even though they are divorced. A counselor is ava11able to discuss these matters with interested parents or attorneys. 